\title{
Decreased bacterial growth on vascular plant detritus due to photochemical modification
}

\author{
Alexandre M. Anesio*, C. Måns T. Denward, Lars J. Tranvik**, Wilhelm Granéli \\ Department of Ecology/Limnology, Lund University, S-223 62 Lund, Sweden
}

\begin{abstract}
We investigated the effects of UV radiation on abiotic decomposition and dissolution of leaf litter from the aquatic macrophyte Phragmites australis. Dead leaves were autoclaved and incubated in quartz tubes with autoclaved Milli-Q water, in darkness, under UVA or under UVA+UVB radiation, using fluorescent tubes with intensities similar to solar radiation. More DOM was produced in irradiated samples compared to dark ones. After exposure, the water was inoculated with a natural assemblage of bacteria and incubated in the dark. Free bacteria reached higher densities in cultures with detritus pre-treated in darkness than in cultures with irradiated substrates. No significant differences in numbers of attached bacteria were found. We suggest that UV-irradiated detritus from $P$. australis has a negative effect on the growth of free living bacteria, possibly due to the leaching of inhibitory substances from the leaf litter into the water and/or a decrease in DOM bioavailability. Similar experiments, using natural solar radiation, indicated that visible light has only a minor effect on leaching of inhibitory substances.
\end{abstract}

KEY WORDS: UV radiation · Leaf litter · Bacteria $\cdot$ Bioavailability $\cdot$ DOM $\cdot$ Solar radiation

\section{INTRODUCTION}

Solar UV radiation affects microorganisms negatively (Calkins \& Thordardottir 1980, Karentz et al. 1991, Herndl et al. 1993). In addition, photochemical transformation of dissolved organic matter (DOM) can result in the production of substances inhibitory for bacteria, such as radicals (Cooper et al. 1989, Scully et al. 1996). Interaction between dissolved humic substances (DHM) and UV radiation can promote the aging of fresh DOM, hence making it less available to bacteria (Tranvik \& Kokalj 1998). Keil \& Kirchman (1994) demonstrated that rates of protein assimilation by bacterial assemblages decreased when the protein was aged in sterile seawater. The aging effect was enhanced by exposure to solar radiation. On the other hand, UV radiation has positive indirect effects on bacteria by the transformation of recalcitrant DOM into more easily degradable forms, resulting in stimulated bacterial growth (Geller 1986, Lindell et al. 1995). This

\footnotetext{
-E-mail: alexandre.anesio@limnol.lu.se

- Present address: Department of Limnology, Evolutionary Biology Centre, Norbyvägen 20, S-75236 Uppsala, Sweden
}

photochemical pathway may be an important source of substrate for bacteria in oligotrophic lakes (Kieber et al. 1989). Hence, photochemical transformation of organic matter may have both positive and negative effects on bacterial growth

Aquatic macrophytes are major primary producers in many aquatic ecosystems, contributing large amounts of both DOM and particulate organic matter (POM) (Mann 1988). The net effect of solar radiation on aquatic macrophyte decomposition is complicated by several direct and indirect, both positive and negative, processes. The role of photochemical processes in the decomposition of organic matter is much less studied in littoral systems than in pelagic ones. Wetzel et al. (1995) exposed humic and fulvic acid fractions of DOM, leached from aquatic macrophyte detritus, to UV radiation. Although the overall change in DOM structure was small, the exposed DOM had a positive net effect on bacterial growth. There is no information on the role of solar radiation promoting the release of inhibitory substances from plant litter. Stable free radicals have been detected in rotted straw and in material containing solubilized lignin components (Pillinger et al. 1996). When the straw had undergone aquatic 
decomposition for up to $6 \mathrm{mo}$, radicals still persisted in association with the straw, and thus microbial activity was inhibited. Possibly, solar radiation plays a role in the formation of these radicals.

Our initial hypothesis was that UV-radiated leaf litter or radiated DOM, originating from macrophyte leaf litter, would support an increased bacterial carrying capacity upon irradiation. In this study, we evaluate the abiotic effects of UV radiation on the decomposition of Phragmites australis detritus. In addition, we demonstrate the inhibition of bacterial growth in response to the photolytic transformation of $P$. australis detritus.

\section{MATERIALS AND METHODS}

Experimental design. Dead leaves of Phragmites australis (Cav.) Trin. ex Steud. were collected from standing dead shoots in Lake Krankesjön (southern Sweden), in March 1996. Leaves were dried at room temperature in the dark for $48 \mathrm{~h}$, and autoclaved dry in quartz tubes. After cooling, autoclaved Milli-Q water was added, leaving no head space in the tubes. After addition of water, leaching of dissolved organic carbon (DOC) was similar for autoclaved and non-autoclaved leaves. Autoclaving did not affect $\mathrm{pH}$ in the water, or carbon and nitrogen contents of the leaf litter (data not shown). Quadruplicate tubes were exposed to different regimes of irradiation under sterile conditions, using lamps or natural solar radiation. After irradiation or darkness the water was inoculated with bacteria by adding an inoculum ( $1 \%$ of the total volume) of GF/F filtered lake water to test for differences in bacterial carrying capacity of the organic carbon source between the various radiation treatments. Solutions of $\mathrm{KH}_{2} \mathrm{PO}_{4}$ and $\mathrm{NH}_{4} \mathrm{NO}_{3}$ were added (final concentration of 5 and $50 \mu \mathrm{M}$ of $P$ or $N$, respectively) to ensure that bacterial biomass accumulation was not limited by $P$ and N. Bacterial carrying capacity was determined through enumeration and size measurements of bacteria. Two experiments were conducted in the laboratory with artificial radiation and a third experiment was performed outdoors with different wavelength bands of natural solar radiation.

First experiment. Leaf litter ( 47 to $51 \mathrm{mg} \mathrm{tube}^{-1}$ ) and DOM leached from the leaves were irradiated with UVA or UVA+UVB, or incubated without radiation, in $40 \mathrm{ml}$ quartz tubes for $72 \mathrm{~h}$. The radiation source consisted of 8 fluorescent tubes (UVA-340, Q-Panel Co., USA) emitting UVA ( $\left.23 \mathrm{~W} \mathrm{~m}^{-2}\right)$, UVB $\left(0.19 \mathrm{~W} \mathrm{~m}^{-2}\right)$, and negligible amounts of PAR $\left(<5 \mathrm{~W} \mathrm{~m}^{-2}\right)$. After $72 \mathrm{~h}$, the total amount of energy corresponded to $6 \times 10^{3} \mathrm{~kJ} \mathrm{~m}^{-2}$ for UVA and $5 \times 10^{2} \mathrm{~kJ} \mathrm{~m}^{-2}$ for UVB. Dark conditions were achieved by wrapping the tubes in aluminum. foil. The tubes were incubated at $19^{\circ} \mathrm{C}$ in a temperature-controlled room. Dissolved inorganic carbon (DIC), DOC and fluorescence of the water were analyzed after irradiation. Thereafter, $10 \mathrm{ml}$ from each tube were transferred into acid rinsed $20 \mathrm{ml}$ glass vials and inoculated with bacteria by adding $0.2 \mathrm{ml} \mathrm{GF/F}$ filtered lake water. The leaf litter was transferred to another vial containing $10 \mathrm{ml}$ of water from the tube and similarly inoculated with bacteria. In this way, we were able to examine bacterial growth on leachates independent of the presence of leaf Jitter. Inorganic nutrients were added and the vials were aerated. The vials were incubated in darkness at $19^{\circ} \mathrm{C}$ for $120 \mathrm{~h}$. Vials were sacrificed for bacterial counts $48,72,96$ and $120 \mathrm{~h}$ after inoculation. Numbers and biomass were determined for bacteria attached to the leaf litter and for free bacteria.

Second experiment. The second experiment was conducted to check for differences in bacterial response to photochemical transformation of DOM alone and of DOM+leaf litter together. Leaf litter (190 to $210 \mathrm{mg}$ tube $\left.{ }^{-1}\right)$ was placed in 16 quartz tubes $(190 \mathrm{ml})$ and autoclaved. Milli-Q water was also autoclaved and added after cooling. Four of the tubes were irradiated with UVA+UVB for $72 \mathrm{~h}$, while 12 tubes were kept in darkness. Measurements of DOC, DIC and fluorescence of DOM were made in the water from the irradiated tubes and for 4 of the dark incubated tubes. From each of these 8 tubes ( 4 irradiated and 4 darkened), $10 \mathrm{ml}$ of water were distributed to each of 12 vials. These vials were inoculated with bacteria as above. The water (leaf litter was then discarded) from the other 8 dark incubated tubes was filtered with VacuCap ${ }^{\text {TM }}$ filters $(0.2 \mu \mathrm{m}$, Gelman Sci.) and transferred to new $190 \mathrm{ml}$ quartz tubes. Half of these were exposed to UVA+UVB radiation, while the rest were kept in darkness. After 72 h, water was processed as above, i.e. distributed to glass vials and inoculated with bacteria. Growth of bacteria was followed for $96 \mathrm{~h}$, with triplicate vials being withdrawn every $24 \mathrm{~h}$ for bacterial measurements.

Third experiment. The third experiment was conducted outdoors with tubes incubated with natural solar radiation. The litter was not autoclaved since the time of exposure ( 6 h) was short enough to avoid any extensive growth of bacteria. The leaf litter was put in $190 \mathrm{ml}$ quartz tubes filled with Milli-Q water, which were then exposed to 4 different treatments: PAR, PAR+UVA, PAR+UVA+UVB (full solar radiation) or no radiation (dark), during a cloudless summer day in Rio de Janeiro $\left(23^{\circ} \mathrm{S}\right.$, Brazil). Radiation values around noon were 455, 35 and $0.50 \mathrm{~W} \mathrm{~m}^{-2}$, and the total amount of energy was $7.7 \times 10^{3}, 5.9 \times 10^{2}$ and $7.0 \mathrm{~kJ}$ $\mathrm{m}^{-2}$, for PAR, UVA and UVB, respectively, during the $6 \mathrm{~h}$ incubation. Plexiglas transparent to visible light 
only (Röhm GS 233) was used to expose tubes to PAR only. UV-transparent Plexiglas (Röhm GS 2458) in combination with Mylar foil was used to expose tubes to PAR+UVA (Granéli et al. 1998). Total solar radiation (PAR+UVA+UVB) was achieved using only UV-transparent Plexiglas. Dark samples were obtained by covering the tubes with aluminum foil. After exposure, the leaves were picked up and the tubes inoculated with filtered lake water ( $1 \%$ of the total volume). The tubes were then incubated for $120 \mathrm{~h}$ in darkness. Samples of $10 \mathrm{ml}$ were taken from the tubes daily over $120 \mathrm{~h}$ for bacterial counts. In an additional set of samples using $40 \mathrm{ml}$ quartz tubes (leaving no head space), bacterial samples were taken only after 120 h of incubation, preceeded by measurements of DIC production as an indicator of bacterial respiration.

Abiotic measurements. DIC was analysed with a Shimadzu TOC-5000 total carbon analyzer immediately after irradiation was terminated. At least 3 measurements were made for each tube, resulting in a coefficient of variation (CV) of less than $2 \%$ (Granéli et al. 1996). Samples $(\sim 6 \mathrm{ml})$ for DOC were taken from the tubes after DIC analysis and transferred into acid rinsed, pre-combusted $\left(+500^{\circ} \mathrm{C}\right.$, overnight) glass vials with Teflon-lined screw caps. Samples were kept in a refrigerator and analysed after a few days. DOC was analysed by the Pt-catalyzed high-temperature combustion method using the Shimadzu TOC-5000 total carbon analyzer equipped with an ASI-5000 auto sampler. Inorganic carbon was purged for 5 min from acidified samples $(\mathrm{pH} \sim 2, \mathrm{HCl})$. For each analysis, a minimum of 3 replicate injections were made on the carbon analyzer, resulting in a CV of less than $2 \%$.

Fluorescence and absorbance measurements were used to show photochemical transformation of DOM. Fluorescence was measured with a Shimadzu RF-1501 spectrofluorometer equipped with a $10 \times 10 \mathrm{~mm}$ quartz cuvette with excitation at $355 \mathrm{~nm}$ and emission at $455 \mathrm{~nm}$ (bandwidth $10 \mathrm{~nm}$ ). Fluorescence was expressed as quinine sulphate units (QSU) and 1 QSU corresponds to the fluorescence of $0.01 \mathrm{mg} \mathrm{l}^{-1}$ quinine sulphate in a $0.1 \mathrm{M} \mathrm{H}_{2} \mathrm{SO}_{4}$ solution. Absorbance was measured at 250 and $365 \mathrm{~nm}$.

Bacterial growth. Numbers of bacteria were estimated using epifluorescence microscopy and flow cytometry. Biomass was estimated measuring cell dimensions with an image analyzer system connected to the microscope via a video camera. In the first experiment, numbers were obtained with epifluorescence microscopy with DAPI-stained samples (Porter \& Feig 1980). A minimum of 300 cells or 30 fields of view were counted for each sample. The last samples (after $120 \mathrm{~h}$ of incubation) were used for measurements of cell volume. Images were captured with Image Grabber-24 software (Neotech) and processed with IPLab Spectrum 3.1a software (Signal Analytics). At least 150 bacteria on 3 images were measured and cell volumes and biomass were calculated using the formula and carbon-to-cell

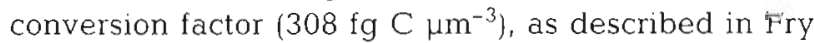
(1988). Attached bacteria were estimated in the same way, after $\mathrm{Na}_{4} \mathrm{P}_{2} \mathrm{O}_{7}$ addition (final concentration of $0.01 \mathrm{Mj}$ and treatment for $5 \mathrm{~min}$ in an ultrasonic bath (Branson 200), to get them into suspension.

In the second and third experiments, bacterial numbers were obtained with a FACSort (Becton Dickinson) flow cytometer according to del Giorgio et al. (1996). Cells were stained with SYTO 13 (Molecular Probes) with a final concentration of $2.5 \mu \mathrm{M}$ and Fluoresbrite ${ }^{\mathrm{TM}}$ Carboxylate Microspheres $(\varnothing=1.58 \mu \mathrm{m})$ were used as reference. Bacterial counts in the epifluorecence microscope always agreed well with flow cytometric counts $\left(\mathrm{r}^{2} \geq 0.95, \mathrm{p}<0.001\right)$.

Respiration of bacteria in the third experiment was followed through measurements of DIC increase with a Shimadzu TOC-5000 total carbon analyzer.

Statistics. Differences in abiotic variables, bacterial numbers and biomass among treatments were tested with 1-way ANOVA, followed by Tukey's post-hoc test. Mann-Whitney $U$-test was done for the field experiment in Brazil, when comparing full radiation treatment against darkness. The statistics were computed using SYSTAT software (Loman 1997).

\section{RESULTS}

Decomposition of Phragmites australis detritus was influenced by UV radiation. Dissolution of leaf litter was higher in the UV treatments than under dark conditions, as shown by the DOC content of the water $(\mathrm{p}<$ 0.05 , ANOVA; Table 1). There were no differences between UVA and UVA+UVB treatments $(p>0.1$, Tukey's test), indicating that UVB had no significant effect on DOM leaching from $P$. australis leaf litter. DIC production increased linearly with time during incubation in the irradiated tubes, while no production of DIC was detectable in darkened tubes. Production of DIC was significantly higher in the treatment containing both UVA and UVB than in tubes treated with UVA alone ( $p<0.01$, ANOVA followed by Tukey's test). The composition of leached DOC, as indicated by specific fluorescence and absorbance patterns, was also significantly different between irradiated and dark samples, but not between the 2 treatments containing UV ( $\mathrm{p}<$ 0.01. ANOVA followed by Tukey's test).

Despite differences between treatments in the dissolved fraction, the bulk composition of leaf litter, as indicated by carbon and nitrogen analysis of leaf litter, was not different between irradiated and dark treatments (Table 2). Dry weight loss of POM was not 
Table 1. Abiotic characteristics of DOM held in dark, or after exposure to UVA and UVA+UVB, respectively, for $72 \mathrm{~h}$. Values in parentheses are standard deviation $(n=4)$. All parameters differed significantly among radiation treatments $(p<0.05$, ANOVA). However, post-hoc tests reveal that, except for DIC, there were no differences between UVA and UVA+UVB (p > 0.05). ND: not determined

\begin{tabular}{|c|c|c|c|c|c|}
\hline Treatment & $\begin{array}{c}\text { DOC } \\
\text { (final concentration) } \\
\left(\mu \mathrm{g} \mathrm{C} \mathrm{mg} \mathrm{DW} W^{-1}\right)\end{array}$ & $\begin{array}{l}\text { Fluorescence } \\
\text { QSU DOC } \\
\text { (DOC in } \mathrm{mg} \mathrm{l}^{-1} \text { ) }\end{array}$ & $\begin{array}{l}\text { Absorbance } \\
250 / 365 \mathrm{~nm}\end{array}$ & $\begin{array}{c}\text { DIC } \\
\text { (final concentration) } \\
\left(\mu \mathrm{g} \text { C mg DW } W^{-1}\right)\end{array}$ & $\mathrm{pH}$ \\
\hline Dark & $9.61(0.95)$ & $0.47(0.06)$ & $4.45(0.15)$ & $0.02(0.01)$ & $4.92(0.06)$ \\
\hline UVA & $12.47(1.36)$ & $0.15(0.01)$ & $5.53(0.46)$ & $0.58(0.02)$ & ND \\
\hline $\mathrm{UVA}+\mathrm{UVB}$ & $13.09(1.73)$ & $0.14(0.01)$ & $5.61(0.42)$ & $0.94(0.13)$ & $4.75(0.04)$ \\
\hline
\end{tabular}

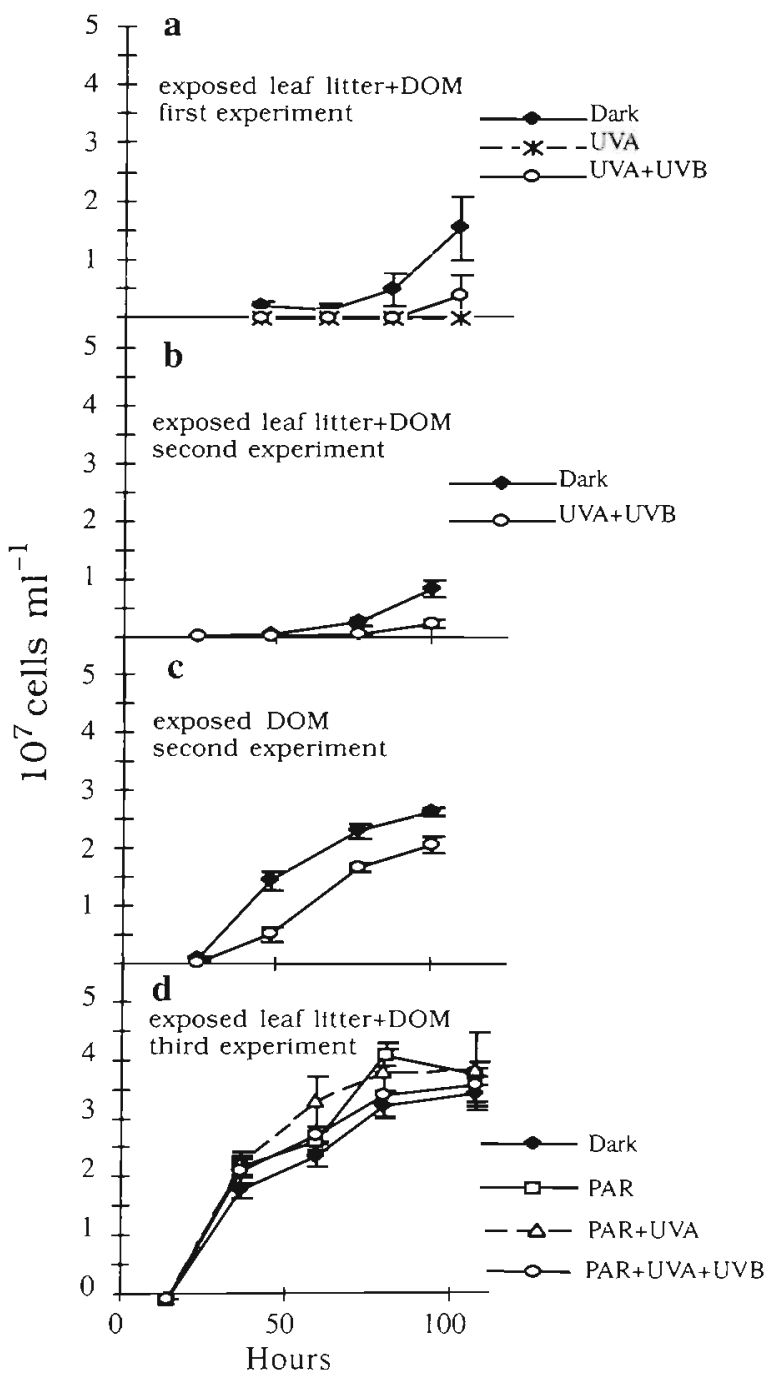

Fig. 1. Bacterial numbers in the cultures using Phragmites australis detritus treated under different radiation regimes for $(a, b, c)$ the laboratory experiments and (d) in Brazil with natural solar radiation

significantly different among treatments $(\mathrm{p}>0.1$. ANOVA). However, a trend of higher loss in the irradiated treatments was detected, which is in accordance with a higher DOC increase in the irradiated water.
Table 2. Organic carbon and nitrogen content of leaf litter of Phragmites australis held in the dark, or exposed to UVA and UVA+UVB, respectively, for $72 \mathrm{~h}$. Values in parentheses are standard deviation $(n=4)$. There were no significant differences between radiation treatments for any of the treatments ( $p>0.1$, ANOVA)

\begin{tabular}{|lcccc|}
\hline Treatment & $\begin{array}{c}\text { Carbon } \\
(\%)\end{array}$ & $\begin{array}{c}\text { Nitrogen } \\
(\%)\end{array}$ & C/N ratio & $\begin{array}{c}\text { Dry weight } \\
\text { loss }(\%)\end{array}$ \\
\hline Dark & $44.16(0.79)$ & $1.01(0.16)$ & $51.78(7.63)$ & $1.03(0.57)$ \\
UVA & $44.10(0.63)$ & $0.93(0.15)$ & $56.40(8.25)$ & $1.45(0.31)$ \\
UVA+UVB & $44.01(0.55)$ & $0.97(0.05)$ & $52.98(2.24)$ & $1.85(0.50)$ \\
\hline
\end{tabular}

Dry weight losses could not be measured with the same precision as DOC changes.

In all experiments in the laboratory, employing UV fluorescent tubes and using only DOM or leaf litter+DOM, the abundance of free bacteria was lower in the irradiated treatments than in cultures with nonirradiated substrates $\left(p<0.05\right.$ ANOVA $_{i}$ Fig. $\left.1 a, b, c\right)$. No differences were found between UVA and UVA+UVB treatments ( $p>0.1$, Tukey's test, Fig. 1a). In the experiments including both DOM and leaf litter, biomass of attached bacteria was not significantly different among dark, UVA or UVA+UVB treatments $(p>$ 0.1. ANOVA; Table 3). Biovolume of free bacteria growing on UV-treated DOM was slightly higher compared to biovolume of bacteria growing on darktreated DOM $(p<0.05, t$-test $)$. However, the difference in biovolume did not cause higher bacterial biomass in culture with UV-treated DOM compared to non-irradiated DOM (Table 3).

When using natural solar radiation, bacterial numbers were not significantly different among the treatments ( $p>0.05$, ANOVA; Fig. 1d). Total energy used to irradiate the substrate was similar for both field and laboratory experiments. However, most of the energy in the in situ experiments was within PAR $(93 \%)$, while energy in the laboratory experiments was almost exclusively UV radiation. In the field, an additional experiment was performed exposing the tubes to total radiation or dark conditions. After bacterial inoculation, the tubes were held in the dark for $120 \mathrm{~h}$ and then 
Table 3. Bacterial biomass at the end of the experiment. The values in parentheses are standard deviation. ND: not determined

\begin{tabular}{|lccc|}
\hline Treatment & $\begin{array}{c}\text { Expt 1 - POM+DOM } \\
\text { (free bacteria) } \\
\left(\mathrm{mg} \mathrm{C} \mathrm{I}^{-1}\right)\end{array}$ & $\begin{array}{c}\text { Expt 1 - POM+DOM } \\
\text { (attached bacteria) } \\
\left(\mu \mathrm{g} \mathrm{mg} \mathrm{DW}^{-1}\right)\end{array}$ & $\begin{array}{c}\text { Expt 2 - DOM } \\
\text { (free bacteria) } \\
\left(\mathrm{mg} \mathrm{C}^{-1}\right)\end{array}$ \\
\hline Dark & $2.20(1.57)$ & $53(12)$ & $3.52(0.44)$ \\
UVA & $\sim 0.00$ & $25(6)$ & $\mathrm{ND}$ \\
UVA+UVB & $0.78(1.54)$ & $74(48)$ & $2.94(0.46)$ \\
\hline
\end{tabular}

exposed to UV radiation. A possible explanation for this is UV-induced formation of inhibitory substances from organic matter. UV irradiation of organic matter can cause chemical reactions that result in the production of oxidizing compounds such as singlet oxygen, hydrogen peroxide and OH-radicals, which may have toxic effects on aquatic microorganisms (Cooper et al. 1989, Scully et al. 1996).

Treatment with UV radiation of drinking water containing humic substances has been observed to reduce biofilm formation in the pipe system (Lund \& Ormerod 1995), indicating that UV irradiation causes the production of compounds that decrease bacterial growth. The inhibition of bacterial growth, after water is treated with UV, can last as long as $7 \mathrm{~d}$ (Lund \& Hongve 1994). The growth of the green algae Selenastrum capricornutum was inhibited for several weeks in UV-treated water (Gjessing \& Källqvist 1991). One could argue that the Milli-Q water used in our experiments would have a very low buffering capacity, causing changes in $\mathrm{pH}$ during UV exposure. We found a small, but significant, decrease in $\mathrm{pH}$ in UV-exposed water compared to dark treatments (Table 1). However, it is unlikely that this minor change in $\mathrm{pH}$ could explain the observed strong negative effect on bacteria.

Ultraviolet radiation can promote the 'aging' of fresh DOM (Keil \& Kirchman 1994, Tranvik \& Kokalj 1998). This may be what happened in the experiment where only DOM (in the absence of leaf litter) was exposed to UV radiation, before inoculation with bacteria (Fig. 1c). In this experiment, bacterial growth was lower with UV-treated substrate. However, the production of inhibitory substances may be more likely to occur when both leaf litter and DOM are exposed to UV, before bacterial inoculation (Fig. 1a,b). In these experiments, bacterial growth was almost undetectable in tubes with irradiated substrate. Experiments with leaf litter+DOM yielded less bacterial growth than experiments with only DOM, even when only dark treatments are compared (Fig. 1b, c, 72 h incubation prior to bacterial inoculation); this corroborates with the idea that bacterial growth in the presence of leaf litter can be inhibited.

Aquatic macrophyte detritus may release substances which can be toxic to aquatic microorganisms. Pillinger et al. (1996) detected a radical associated with barley-straw Hordeum vulgare, which persisted throughout 6 mo of aquatic decomposition. Hence, inhibitory substances may be long-lived. Introduction of barley-straw into a reservoir was followed by a significant reduction in phytoplankton, chlorophyll a level and cyanobacterial dominance (Everall \& Lees bacterial growth on DOM leached from plant detritus
Unexpectedly, we found a significant decrease in

natural waters (Kieber et al. 1989). Photochemical breakdown of large molecules into simple organic substances may substantially increase DOC availability to bacteria (Lindell et al. 1995, Wetzel et al. 1995). bacterial growth on DOM leached from plant detritus

Table 4. Bacterial numbers and bacterial respiration in Expt 3.

Our initial expectation was that the carrying capactreated plant detritus, due to changes in the quality of organic matter and the quantity of DOM leached from leaf litter. This was based on previous findings of radivik 1998), and increasing bacterial carrying capacity of DOM (e.g. Lindell et al. 1995). There was an increase in DOC released after UV treatments, a lower fluorescence per unit of DOC, as well as a higher 250/365 nm amount and characteristics of DOC, possibly including production of low-molecular-weight (LMW) organic molecules. LMW organic molecules are photochemically produced from the recalcitrant portion of DOM in Quartz tubes with Phragmites australis detritus were exposed probability of dark and irradiated treatments being similar sampled for bacterial abundance and DIC production
(Table 4). Bacterial numbers and respiration (measured as DIC production) were slightly lower in the
tubes with irradiated substrate in comparison to the non-irradiated substrate.

\section{DISCUSSION}


1996). One important component of barley-straw is lignin, which is ubiquitous in vascular plants. Photolysis of DOM leached from aquatic macrophytes can increase its availability to microbes (Wetzel et al. 1995). However, prolonged exposure of the substrate, as well as short time exposure to high-energy UV radiation, may decrease DOM bioavailability. Wetzel et al. (1995) (see their Fig. 1c) reported lower bacterial production on macrophyte detritus that had been exposed to high-energy UV radiation (below $290 \mathrm{~nm}$ ) for $2 \mathrm{~h}$, compared to non-irradiated detritus. Vascular plants synthesize a number of secondary metabolites, such as tannins and complex phenolic compounds, as a consequence of damage caused by herbivory (Findlay et al. 1996) and even UVB radiation (Gehrke et al. 1995). These materials are very resistant to decomposition and may inhibit decomposers after leaching to the water (Findlay et al. 1996).

In the experiment with leaf litter+DOM, a reduction in bacterial growth was observed when detritus was treated with UVA radiation only (Fig. 1a). Energyweighted quantum yields indicate that UVA has a significant impact on the photochemical formation of $\mathrm{H}_{2} \mathrm{O}_{2}$ in lakes (Scully et al. 1996). We measured bacterial growth on Phragmites australis detritus on several occasions. In the experiments where we found inhibition, an artificial light source was used, emitting a total of $6456 \mathrm{~kJ} \mathrm{~m}{ }^{-2}$ of energy (UVA+UVB). Subsequently, an experiment was performed using natural solar radiation in Brazil for 6 h resulting in a total energy of $8314 \mathrm{~kJ} \mathrm{~m}^{-2}$, where most of the energy was in the PAR region $(93 \%)$. In this case, there was no inhibitory effect on bacterial growth (Fig. 1d). Although PAR radiation can cause photooxidation of DOC in lakes (Granéli et al. 1998), PAR might not be responsible for the formation of toxic substances.

Reduced bacterial growth was found on organic matter exposed to artificial UV radiation as compared to dark treatments, while no such inhibition of bacterial growth was detectable for organic matter exposed to $6 \mathrm{~h}$ of tropical natural solar radiation. This difference could have been due to the appreciable higher UV dose used in the laboratory experiments as compared to the incubation under natural solar radiation. Although the total UV dose in the laboratory ( $72 \mathrm{~h}$ ) was high, the intensity was comparable to natural solar radiation. Possibly, longer periods of radiation in natural habitats, i.e. several diurnal cycles, result in inhibition in a similar way as found in the laboratory study.

Our results suggest that UV-irradiated Phragmites australis detritus negatively affects the growth of bacteria. Possible explanations include UV-induced formation or release of toxic substances from leaf litter, or UV-induced aging of fresh DOC, making it less bioreactive.
Acknowledgements. This work was supported by grants of the Brazilian Research Council (CNPq) to A.M.A., the Swedish Natural Science Research Council (NFR) to L.J.T and W.G. (B-AA/BU 04969-320), and the Environmental and Climate Program of the European Commission (MICOR project to L.J.T.). Travel grants to Brazil were given by the Swedish Foundation for International Cooperation in Research and Higher Education (STINT 96/94 (97) to W.G.). The staff of the Limnological Laboratory at the Federal University of Rio de Janeiro, particularly Bias Marçal de Faria and Prof. Francisco de Assis Esteves, kindly assisted us during the work in Brazil. Dr Måns Lindell is greatly acknowledged for constructive discussions and practical advice. We are also grateful to Lars-Ake Gisselson for his assistance in the flow cytometer analyses and Ramunas Stepanauskas for his assistance with the image analyzer system.

\section{LITERATURE CITED}

Calkins J, Thordardottir T (1980) The ecological significance of solar UV radiation on aquatic organisms. Nature 28.3: $563-566$

Cooper WJ, Zika RG, Pestane RG, Fisher AM (1989) Sunlight induced photochemistry of humic substances in natural waters: major reactive species. Adv Chem Ser 219:333-362

del Giorgio P, Bird DF, Prairie YT, Planas D (1996) Flow cytometric determination of bacterial abundance in lake plankton with the green nucleic acid stain SYTO 13. Limnol Oceanogr 41:783-789

Denward CMT, Tranvik LJ (1998) Effects of solar radiation on aquatic macrophyte litter decomposition. Oikos 82:51-58

Everall NC, Lees DR (1996) The use of barley-straw to control general and blue-green algal growth in a Derbyshire reservoir. Water Res 30:269-276

Findlay S, Carreiro M, Krischik V, Jones CG (1996) Effects of damage to living plants on leaf litter quality. Ecol Appl 6: $269-275$

Fry JC (1988) Determination of biomass. In: Austin B (ed) Methods in aquatic bacteriology. John Wiley \& Sons, New York, p 27-72

Gehrke C, Johanson U, Callaghan TV, Chadwick D, Robinson $\mathrm{CH}$ (1995) The impact of enhanced ultraviolet- $B$ radiation on litter quality and decomposition process in Vaccinium leaves from the Subarctic. Oikos 72:213-222

Geller A (1986) Comparison of mechanisms enhancing biodegradability of refractory lake water constituents. Limnol Oceanogr 31:755-764

Gjessing ET, Källqvist T (1991) Algicidal and chemical effect of u.v. radiation of water containing humic substances. Water Res 25:491-494

Granéli W, Lindell M, Tranvik L (1996) Photo-oxidative production of dissolved inorganic carbon in lakes of different humic content. Limnol Oceanogr 41:698-706

Granéli W, Lindell M, De Fàia BẤ, Lsteves FA (1998) Fhotoproduction of dissolved inorganic carbon in temperate and tropical lakes - dependence on wavelength band and dissolved organic carbon concentration. Biogeochemistry 43: 175-195

Herndl GJ, Müller-Niklas G, Frick J (1993) Major role of ultraviolet- $B$ in controlling bacterioplankton growth in the surface layer of the ocean. Nature 361:717-719

Karentz S, Cleaver JE, Mitchell DL (1991) DNA damage in the Antarctic. Nature 350:28

Keil RG, Kirchman DL (1994) Abiotic transformation of labile protein to refractory protein in sea water. Mar Chem 45 $187-196$ 
Kieber DJ, McDaniel J, Mopper K (1989) Photochemical source of biological substrates in sea water: implications for carbon cycling. Nature 341:637-639

Lindell M, Granéli W, Tranvik LJ (1995) Enhanced bacterial growth in response to photochemical transformation of dissolved organic matter. Limnol Oceanogr 40:195-199

Loman J (1997) Systat v.5 och 6: statistik och figurer för DOS Windows och Macintosh, ett kompendium. University of Lund

Lund V, Hongve D (1994) Ultraviolet irradiated water containing humic substances inhibits bacterial metabolism. Water Res 28:1111-1116

Lund V. Ormerod K (1995) The influence of disinfection processes on biofilm formation in water distribution systems Water Res 29:1013-1021

Mann KH (1988) Production and use of detritus in various freshwater, estuarine, and coastal ecosystems. Limnol Oceanogr 33:910-930

Editorial responsibility: Faroog Azam,

La Jolla, California, USA
Pillinger JM, Cooper JA, Harding CJ (1996) Stable free radical from plant litter decomposing in water. J Chem Ecol 22:1001-1011

Porter KG, Feig YS (1980) The use of DAPI for identifying and counting aquatic microflora. Limnol Oceanogr 25 : 943-948

Scully NM, McQueen DJ, Lean DRS (1996) Hydrogen peroxide formation: the interaction of ultraviolet radiation and dissolved organic carbon in lake waters along a $43-75^{\circ} \mathrm{N}$ gradient. Limnol Oceanogr 41:540-548

Tranvik L, Kokalj S (1998) Decreased biodegradability of dissolved organic carbon of phytoplankton origin due to interactive effects of UV radiation and humic matter. Aquat Microb Ecol 14:301-307

Wetzel RG, Hatcher PG, Bianchi TS (1995) Natural photolysis by ultraviolet irradiance of recalcitrant dissolved organic matter to simple substrates for rapid bacterial metabolism. Limnol Oceanogr 40:1369-1380

Submitted: February 9, 1998; Accepted: September 20, 1998 Proofs received from author(s): May 25, 1999 